\title{
A Categorization of City Slogans Drawing on Examples from Hungarian Cities
}

\author{
Dr. habil. Árpád PAPP-VÁRY \\ General Vice-Rector, Dean of the Business, \\ Communication and Tourism Faculty \\ Budapest Metropolitan University, Hungary \\ E-mail: apappvary@metropolitan.hu
}

\section{Máté FARKAS}

Senior PR-expert

One on One Communications Budapest, Hungary

E-mail: mate.farkas@oneonone.hu

\begin{abstract}
In addition to logos, slogans may be the most tangible elements in the marketing and communications of a city. Slogans are good if they capture the character and story of the city, distinguish it from other places, and are capable of inspiring tourists, investors, and, not least, locals. However, if slogans are ordinary and meaningless, they may do more harm than good. "The colourful city", "The livable city", "The friendly city", "Explore (city)", "A city that's different", or "In the heart of Europe" are slogan efforts that have been used a thousand times before and will only make their user look ridiculous. Therefore, this study first examines what elements make a good slogan. What aspects should professionals consider when creating a slogan? What examples can we see in the United States of America, a country often considered as the homeland of branding (and city branding)? These questions are followed by a discussion of examples from Hungarian cities. The touristic attributes of the country serve as a starting point, but how much do traditionally define main guidelines involving health, active, wine and gastrotourism appear in the slogans of Hungarian cities? Having classified 133 slogans from
\end{abstract}


91 cities into various categories, we can see if Hungarian cities reinforce clichés, or provide a good example.

Keywords: Place marketing; City marketing; Place branding; City branding; Slogan; Verbal identity; Hungary.

JEL classification: M31, M39

\section{Introduction: What makes a city slogan good?}

If we are looking for the origin of the word 'slogan', we must travel back to Gaul in time and space. Gallic people used the word 'sluagh-ghairm' as a battle cry (Healey 2009). Although we do not use the word as a battle cry anymore, we can be sure that similarly to brand names, slogans are an extremely effective tool for the development of brand equity - as Kotler, "the Pope of Marketing" and Keller, one of the most famous experts of branding wrote in their book Marketing Management (2006, p. 378.).

They also highlight that the role of the slogan is to provide a reference point or clue to customers in order make them understand what's behind the brand, and what makes it special (Kotler-Keller 2006, pp. 378-379).

However, it is not easy to define what makes a good slogan. The book The power of brand names summarized the aspects of a good slogan the following way (Papp-Váry 2013):

-It 'grabs' positioning

-It has a clear message and communicates the 'story' of the product

-It is attractive and includes 'consumer and customer' advantage

-It carries a positive connotation (or at least it is not negative)

-It is inspiring: it urges us to buy the product, or get more information about it

-It is relatively short (not longer than 5 words)

-It differentiates: it is unique, original, and different from competitors

-It can be used and sustained on a long term, and the brand (owner) does not have to replace it

-It is easy to memorize and repeat

-It harmonizes with the logo

-It is catchy and witty

-Clients -and colleagues - like it.

As it was pointed out above, one of the roles of a slogan is to 'grab' positioning. Of course, positioning must be defined before a slogan is created. This involves the consideration of four aspects (Ries - Trout 1997, Papp-Váry 2011):

1. What are the strengths of the product/service, or the city?

2. What do 'customers' need? 
3. What is the positioning of 'competitors', that is, other cities?

4. What global macrotrends can we see that we can build on?

Based on the above, the following positioning sentence must be defined: "... is the only product in the product category that is different from its competitors in ...".

In the context of cities, this means: "... (name of the city) is the only place (in the specific country or county) that is different from all other cities in ... and ... (in that region)".

Again, it is important to note that this is not the slogan yet, but a strategic idea describing the uniqueness of the city.

Good positioning also has a positive influence on city development and the improvement of city communications. However, if there is no positioning, the outcome is meaningless slogans (See e.g. Baker 2007).

It is worth examining what kind of city slogans we see in the United States, which may be called the cradle and leading country of branding.

Several rankings of city slogans have been created, but most of them included the same slogan in the first position: 'What Happens Here, Stays Here'. The sentence is a great match for a city famous for its nightlife, and, especially, gambling. Of course, the city is Las Vegas.

However, even for Las Vegas, it took long to find this slogan (E.g. Pride 2004). Before that, they used slogans such as:

-'The American way to play'

-'No one does it better'

-'The entertainment capital of America'

-'Las Vegas is Las Vegas'.

The latter may have sounded overly confident, as if the city slogan had nothing else to say about Las Vegas. However, it was a good idea to include the name of the city. It is no wonder that some experts say that the current slogan ('What Happens Here, Stays Here') would sound better this way: 'What Happens in Vegas, Stays in Vegas'.

The inclusion of the city name in the slogan is justified by the fact that several cities that made the Top 100 list of slogans used this solution (See Tagline Guru 2011):

-'Only in San Francisco' (San Francisco, California)

-'Cleveland Rocks!' (Cleveland, Ohio)

-'Keep Austin Weird' (Austin, Texas)

-'Experience our Sense of Yuma' (Yuma, Arizona)

-'Newark, on a Roll' (Newark, New Jersey)

-'You Can Do Better in Can Do' (Cando, North-Dakota)

-'Livable, Lovable, Lodi' (Lodi). 
The latter two are also interesting in another sense. Cando utilized the wordplay originating from the name of the city ('Can Do'), while in the case of Lodi, the alliteration makes the slogan unique and easy to remember, even if a 'livable and lovable city' is more of a cliché.

The slogan of Tombstone, Arizona uses alliteration and some sort of wordplay together: 'The Town Too Tough to Die'.

Cities with names carrying possible wordplay are lucky. Besides the abovementioned Cando and Tombstone, examples include:

-'The City Was So Nice They Named it Twice' (Walla Walla, Washington)

-'Where Chiefs Meet' (Meeteetse, Wyoming).

It is at least as favourable if the character and positioning of a city provide a starting point:

-'Where Yee-Ha Meets Olé' (Eagle Pass, Texas)

-'The Aliens Arent't the Only Reason to Visit' (Roswell, New Mexico) (Referring to the extraterrestrial events taking place around the city)

-'The City That Never Sleeps' (New York City, New York)

-'The Sweetest Place on Earth' (Hershey, Pennsylvania) (Referring to the chocolate brand)

-'The Richest Place on Earth' (Virginia City, Nevada) (The city was famous for its silver mining in the 1800s, and used to be the richest city in the United States)

-'Where The People Are Warm Even the Weather Isn't' (Andover, Kansas) (Referring to the big tornado in 1991)

-'City with a Mission' (San Gabriel, California) (Referring to Gabriel Archangel, the eponym of the city, and the famous Catholic mission there)

-'It's not the end of the world but you can see it from here' (Bushnell, South Dakota) (Referring to the location and small size of the city).

However, cities in the US do not only provide good examples. Two slogans that do not really differentiate, or inspire:

-'The City Different' (Santa Fe, New Mexico)

-'Something to Remember' (San Antonio, Texas).

Based on the slogans above, we can state that it is always good if a slogan is characterized by factuality and musicality (E.g. Hildreth 2013).

If an advertiser manages to find an interesting fact, then it should be included in the slogan. However, it is also important that such facts must be real facts, that is, it should feature real information. Two examples:

Some time ago London used to use the slogan 'Visit London: it rains more in Rome'. (This assertion may be fact-checked: the annual amount of rain is actually higher in Rome.) 
The choice of Yubari, a Japanese town was the following slogan: 'No money but love'. (The town actually went bankrupt in 2007. They hired an advertising agency who found an exciting fact: Yubari had the lowest number of divorces in the country. Therefore, the slogan 'no money but love' turned into a kind of positioning that served as a basis of business. The mayor held a press conference and announced that Yubari is the city of happy couples. They also established a small office, where locals and tourist couples could 'reinforce' their marriage. Shortly, the number of couples visiting the city was 3,000. To make the idea come alive, they also created a mascot for the city, called Yubaru Fusai - as the word 'Fusai' means debt and married couple at the same time. However, the most exciting part of the story was the local support that the idea received. Within a short time, they offered Yubari Fusai branded books and notebooks, produced a CD with a selection of love songs, and also sold branded chocolate and beer. However, the most popular part of the concept was the Yubari Fusai mascot - which is no wonder in a country where people are so fond of Hello Kitty. The slogan 'No money but love' resulted in a lot of press coverage including TV, radio, newspapers and online. The city received several encouraging positive comments in the the digital space, and many people googled its name. Quite many of them also visited the place: in Yubari, tourism increases by 10 per cent each year, and the campaign received several awards at the Cannes advertising contest. Incomes are also increasing; therefore, the city debt is decreasing. Of course, if the debt was over, they would also need to replace the beginning of the slogan 'no money but love'.

Besides factuality, the other important aspect is musicality. "Quite plainly, the way the words sound. Rhythm. Cadence. Tone. Timbre. Vibrato. Phrasing. When it comes to a slogan, these things matter a lot. (...) It's what you say and the way that you say it." (Hildreth 2013, p. 222).

But let us return to the USA and slogans - even if the following examples are not traditional slogans. The reason is that several American settlements have been accompanied by nicknames in the past years, decades, centuries. Sometimes these are more popular than the official slogan, and it is always an advantage if a city possesses one:

-New York: 'The Big Apple'

-Las Vegas: 'Sin City'

-Los Angeles: 'La-La Land'

-Philadelphia: 'The City of Brotherly Love'

-Liberal, Kansas: 'The Land of Oz'

-Miami:'Vice City'

-Detroit: 'Motor City'

-Chicago: 'The Windy City'

-Salem: 'City of Witches' 
-Houston: 'Space City'

-Huntington Beach: 'Surf City'.

\section{The slogans of Hungarian cities - A possible categorization}

In the light of the above, it may be useful to examine what slogans are used by major Hungarian cities, and how these slogans can be categorized.

It should be noted that some slogans may not be accurate as several cities (for example, Győr) change their slogans at short intervals. In other cases, cities use different slogans on their materials for various purposes, using multiple slogans to target different groups such as tourists, investors, locals, etc. There are also examples of slogans created specifically for EU projects, for example, 'Faith and health' in the case of Nyíregyháza and Nyírbátor. Sometimes we do not even know if a slogan is the official motto of the city, it was created by the tourism destination management (TDM) organization, or someone just uploaded a video on Youtube with a slogan that became popular afterwards. In any case, using too many slogans has a negative effect on the city brand: it is confusing for tourists and investors, and even worse in a sense, it also confuses locals.

But let us take a closer look at the slogans themselves. We classified 133 slogans from 91 Hungarian cities into categories according to their most characteristic use. Some slogans can be included in multiple categories, as our classification can be realistic on the whole this way.

\section{Category 1: Slogans including the word 'city'}

First we must examine the question if the slogan of a city should include the word 'city' at all, because if there is one thing that we know (almost) for sure about a city is that it is a city. Is it a reason to leave out the word 'city', or is it a reason to include it? Both arguments are logical in a way.

Out of all Hungarian analyzed examples, 57 slogans of 45 cities include the word "city", which means that half of the 91 examined cities use this expression. Municipalities in Hungary must satisfy several serious conditions in order to qualify as a city, and the most important of all is that the population must be at least 10,000 . Current trends such as internal and foreign emigration and youth drain result in less municipalities eligible to step a level up. Municipalities therefore tend to base their slogans on the word "city" as a kind of privilege.

Of course the word "city" would not provide enough information for branding, and distinction is provided by two or three additional words. We can also find good and less creative examples of positioning in Hungary.

The slogan of the city of Gyula ('A historic spa town') belongs to the first group. The elaborate message is based on the sights of the city, and provides an "umbrella" which allows the creation of further communications messages. The main 
sights of the city are the castle and the castle theatre. The castle is a monument of history, and it provides visitors with a promise of a relaxing experience alongside its bath.

Many places base their marketing on historical monuments from the middle ages and notable events. In addition, Hungary also has a city of kings and a city of queens: Székesfehérvár (The 'King city') is the city of Kings from the Árpád dynasty, and Veszprém ('The city of queens') used to be the burial site of queens. Szigetvár is famous of its heroic struggle with the Turks, and its slogan ('The most heroic city') is also a reminder of this.

It sounds historical, but the slogan of Kecskemét ('Hírös city') was probably created as a result of a special dialect typical of the region. As this term has been used for distinction in various forums and events, people can identify the city according to it.

\section{Subgroups: Garden city and capital city}

Gyál and Érd could be called "garden cities" in the context of the agglomeration of Budapest, as both places focus on the demand wishing to move out of the hassle of the capital, but probably working there. Gyál suggests rapid development with the slogan 'The innovative garden city', and Érd emphasizes its leading role in the region with the term 'The flourishing garden city'.

Slogans including the word "capital" also belong to this category: according to this, Hungary has 10 capitals at the moment (none of them being Budapest). Actually, Lake Balaton has two: Keszthely and Siófok also aspire to hold the title, although the latter levels up, claiming that it is also the capital of summer (Keszthely: 'The capital of Balaton'. Siófok: 'The capital of summer' and 'The capital of Balaton').

Besides emphasizing the geographical location (e.g. Karcag - 'The capital of Nagykunság'), there are unique examples of city slogans, for example that of Békéscsaba, focusing on gastronomy ('The capital of sausage'), or Pécs, a city that tries to use the slogan 'The capital of science', not necessarily to impress tourists, but companies moving to the city. Pécs is also ranking well in the list of slogans per city: besides the scientific slogan mentioned above, the city is also associated with modern arts, Mediterranean atmosphere and culture. Their fifth slogan, 'The borderless city' (or 'The city with no boundaries') might have been created as a summary of all these, but this might have resulted in losing the opportunity to possess a keyword that is extremely important in marketing communications.

According to its slogans, Györ is the city of meetings and rivers, and future is being built there. They would resolve the communications problem with the slogan' One city, a thousand experiences', and - similarly to Pécs - they probably fell into the trap that they created a message that was too general, and did not re- 
ally summarize the attractions of the city. (We use the word "probably" because the slogan may still be successful if they create a good marketing communications concept around it.)

Budapest, the "real" capital of the country is facing a similar problem: it has found the solution to communicate its numerous benefits and promises with the slogan 'The city that unites'. As the country's center of administration, transport, politics, culture, trade and industry it would probably have at least ten slogans in the case of a differentiated use of slogans, that is, there are this many slogans of Budapest around.

In addition to the examples mentioned in this chapter, slogans based on wine and water will be examined in a separate category as a result of their frequent occurrence.

Table 1. Slogans including the word 'city'

\begin{tabular}{|c|c|c|}
\hline City & Slogan (HUN) & Translation (ENG) \\
\hline Balatonfüred & 'A kultúra városa' & 'The city of culture' \\
\hline Békéscsaba & 'A kolbász fővárosa' & 'The capital of sausage' \\
\hline Budapest & 'A város, amely egyesit' & 'The city that unites' \\
\hline Csorna & 'A Rábaköz fövárosa' & 'The capital of Rábaköz' \\
\hline Debrecen & 'A Napba öltözött város' & 'The city clothed in Sun' \\
\hline Dunakeszi & 'A mi városunk' & 'Our city' \\
\hline Eger & $\begin{array}{l}\text { 'A fürdőváros' } \\
\text { 'A barokk város' }\end{array}$ & $\begin{array}{l}\text { 'The spa city', } \\
\text { 'The Baroque city' }\end{array}$ \\
\hline Érd & 'A virágzó kertváros' & 'The flourishing garden city' \\
\hline Fertőd & 'A muzsika városa' & 'The city of music' \\
\hline Gödöllő & 'A megújuló értékek városa' & 'The city of renewing values' \\
\hline Gárdony & 'A Velencei-tó fővárosa' & 'The capital of the Velence Lake' \\
\hline Gyál & 'Az innovatív kertváros' & 'The innovative garden city' \\
\hline Gyöngyös & 'A szőlő és a bor városa' & 'City of grape and wine' \\
\hline Györ & $\begin{array}{l}\text { 'A találkozások városa', } \\
\text { 'A folyók városa', } \\
\text { 'Egy város, ezer élmény' }\end{array}$ & $\begin{array}{l}\text { 'The city of meetings', } \\
\text { 'The city of rivers', } \\
\text { 'One city, a thousand experiences' }\end{array}$ \\
\hline Gyula & 'A történelmi fürdőváros' & 'A historic spa town' \\
\hline Kaposvár & $\begin{array}{l}\text { 'A lehetőségek városa', } \\
\text { 'A legvirágosabb magyar város' }\end{array}$ & $\begin{array}{l}\text { 'The city of opportunities', } \\
\text { 'The most flowery Hungarian city' }\end{array}$ \\
\hline Karcag & 'A Nagykunság fővárosa' & 'The capital of Nagykunság' \\
\hline Kazincbarcika & 'Színes város' & 'Colourful city' \\
\hline Kecskemét & 'Hírös város' & 'Hírös city' \\
\hline Keszthely & 'A Balaton fővárosa' & 'The capital of Balaton' \\
\hline Kiskunhalas & 'A csipke városa' & 'City of lace' \\
\hline Makó & $\begin{array}{l}\text { 'Virágos, vendégszerető kisváros } \\
\text { a Maros partján' }\end{array}$ & $\begin{array}{l}\text { 'Flowery, hospitable small town } \\
\text { by the Maros River' }\end{array}$ \\
\hline Miskolc & 'A nyitott kapuk városa' & 'The city with open gates \\
\hline Mosonmagyaróvár & 'Virágzó város' & 'Flourishing city' \\
\hline
\end{tabular}




\begin{tabular}{lll}
\hline \multicolumn{1}{c}{ City } & \multicolumn{1}{c}{ Slogan (HUN) } & \multicolumn{1}{c}{ Translation (ENG) } \\
\hline Nagykörös & 'A megújuló város' & 'The renewing city' \\
Paks & 'Az együttmüködés városa' & 'The city of cooperation' \\
& 'A kultúra városa', & 'The city of culture', \\
& 'A mediterrán hangulatok városa', & 'The city of Mediterranean impressions', \\
& 'Határtalan város', & 'The borderless city', \\
Pécs & 'A tudomány fövárosa', & 'The capital of science', \\
& 'A modern müvészetek városa' & 'The city of modern arts' \\
& 'A Zemplén fövárosa' & 'The capital of Zemplén' \\
Sátoraljaújhely & 'A vár városa' & 'The city of the castle' \\
Siklós & 'A nyár fövárosa', & 'The capital of summer', \\
Siófok & 'A Balaton fövárosa' & 'The capital of Balaton' \\
& 'A hüség és a szabadság városa', & 'The city of freedom and loyalty', \\
Sopron & 'A Kékfrankos városa' & 'The city of Blaufränkisch' \\
Szécsény & 'A fejedelmi város' & 'The princely city' \\
Szeged & 'A napfény városa' & 'The city of sunshine' \\
Székesfehérvár & 'A királyok városa' & 'King city' \\
Szekszárd & 'A jövő városa', & 'The city of future', \\
Szigetvár & 'Az élhető város', & 'The livable city', \\
Szolnok & 'A leghösiesebb város' & 'The most heroic city' \\
Szombathely & 'A Tisza fövárosa' & 'Capital of the Tisza' \\
Tapolca & 'Szent Márton városa' & 'The city of Saint Martin' \\
Tata & 'A barlangok és vizek városa' & 'The city of caves and waters' \\
Tiszakécske & 'A vizek városa' & 'The city of gardens and waters' \\
Tolcsva & 'A napfény és a vizek városa' & 'The city of sunshine and waters' \\
Verpelét & 'A kastélyok városa' & 'The city of castles' \\
Veszprém & 'Bor és a nóta városa' & 'The city of wine and song' \\
Villány & 'A királynék városa' & 'The city of queens' \\
\hline & 'A bor városa' & 'City of grape and wine', \\
\hline
\end{tabular}

Source: Collection of the author for a tourism project in 2017

Examples of Hungarian cities with slogans including the word 'city' (Illustration 1): Veszprém: 'The city of queens' ('A királynék városa'), Kiskunhalas: 'City of lace' ('A csipke városa'), Szolnok: 'Capital of the Tisza' ('A Tisza fővárosa'), Szekszárd: 'The livable city' ('Az élhető város'), Balatonfüred: 'The city of culture' ('A kultúra városa'), Paks: 'The city of cooperation' ('Az együttmüködés városa'), Szécsény: 'The princely city' ('A fejedelmi város'), Verpelét: 'The city of wine and song' ('Bor és a nóta városa'), Gödöllő: 'The city of renewing values' ('Megújuló értékek városa'), Győr: 'One city, a thousand experiences ('Egy város, ezer élmény'), Mosonmagyaróvár: 'Flourishing city' ('Virágzó város').

Although we realize that it is a city, this slogan by Budapest, the capital of Hungary, does not say much about the city (Illustration 2): "The city that unites (A város, mely egyesít)". 

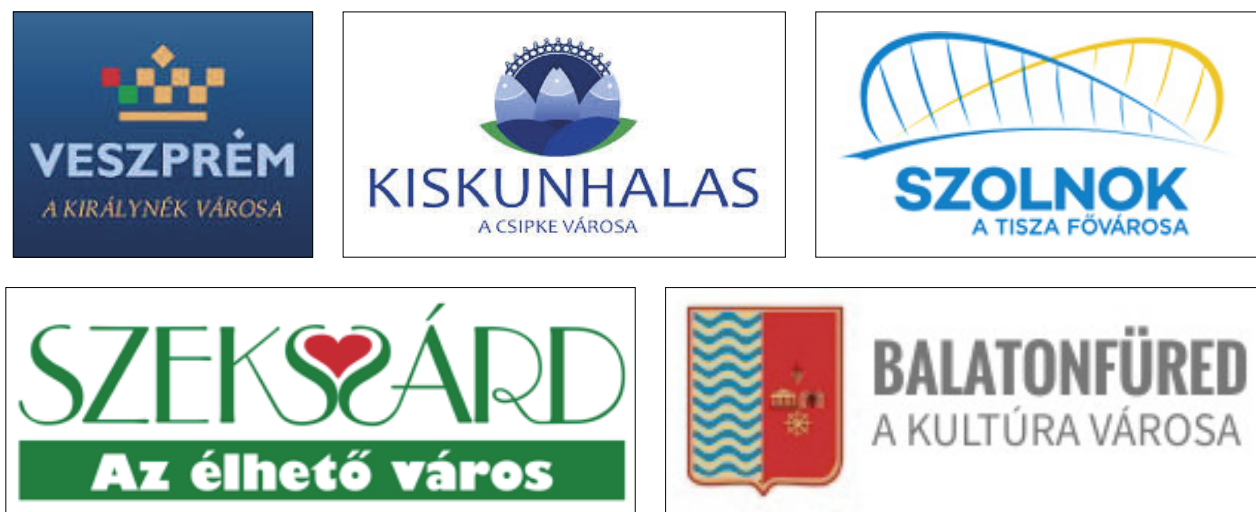

\section{BALATONFÜRED A KULTÚRA VÁROSA}

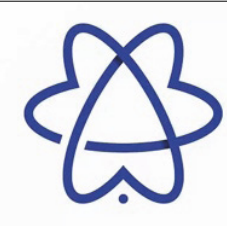

PAKS

az együttműködés városa
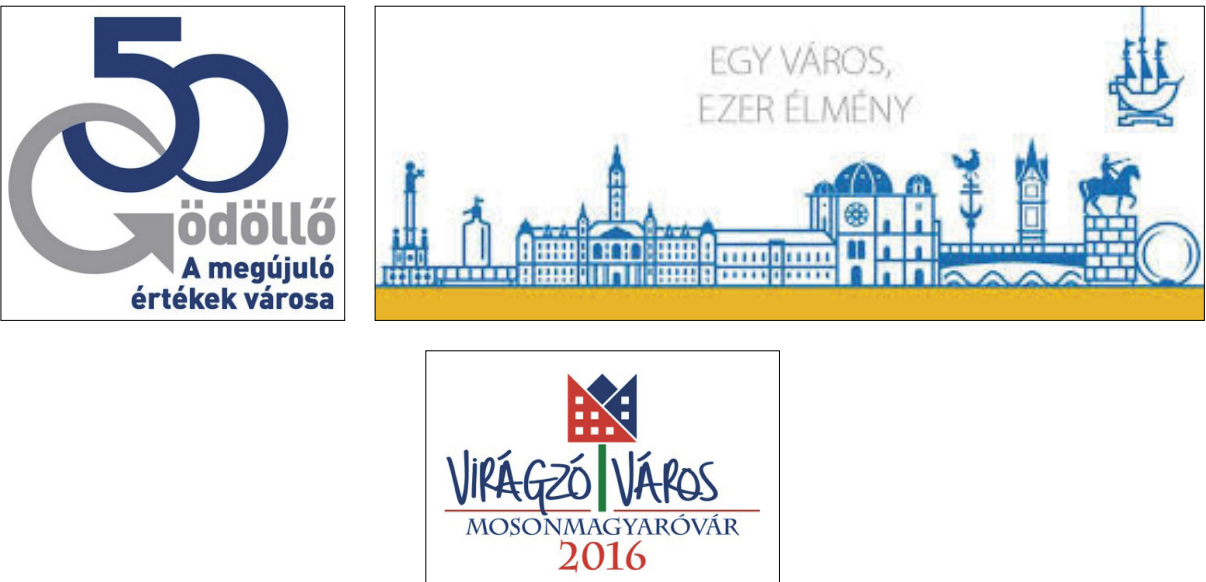

Illustration 1
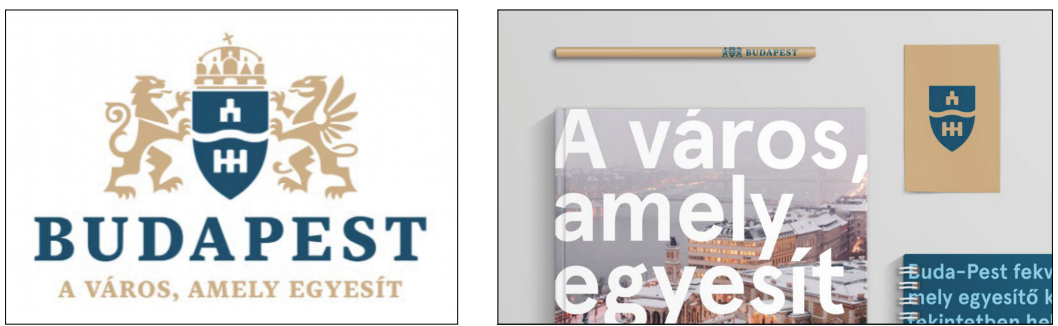

Illustration 2 


\section{Category 2: Slogans including the name of the city}

David Ogilvy's advice (2001) suggesting that brand names should be included in the headline in some form is taken into account in 14 slogans from 12 cities. Smart examples include the slogan 'Aranygombos and Telkibánya invites, welcomes and awaits you again', rhyming well in its original Hungarian version. The place is a popular hiking location, providing delicious food and wines for tired hikers as some sort of a welcoming holiday park. The list of playful slogans is further strengthened by the example of Nagykanizsa: 'Big dreams, big opportunities, Nagykanizsa', which is a little similar to the slogan 'Today, Tomorrow, Toyota' (Big means 'Nagy' in Hungarian). The 'Freedom, Szentes, I love it' slogan focuses on stimulating interest, but it does not necessarily support the positioning of the city as the slogan does not say anything about the city.

A classic example of a wrong slogan is using the term 'More than', which appears in the case of several Hungarian cities. Nyíregyháza, one of the biggest cities in Eastern Hungary uses the slogan 'Nyíregyháza gives you more than you would think', which seem too general at first sight. However, we must also add that the city has undergone rapid development in recent decades, therefore they try to communicate this momentum towards investors and tourists.

The 'Me, You, Győr!' slogan used by the city of Győr may also be too general, similarly to the 'Absolutely Debrecen' and 'Debrecen calling' messages commu-

Table 2. Slogans including the name of city

\begin{tabular}{|c|c|c|}
\hline City & Slogan (HUN) & Translation (ENG) \\
\hline Debrecen & $\begin{array}{l}\text { 'Abszolút Debrecen', } \\
\text { 'Debrecen hív!' }\end{array}$ & $\begin{array}{l}\text { 'Absolutely Debrecen', } \\
\text { 'Debrecen calling' }\end{array}$ \\
\hline Győr & 'Én, Te, Győr!' & 'Me, You, Győr!' \\
\hline Dombóvár & 'Természetesen Dombóvár!' & 'Naturally Dombóvár' \\
\hline Hajdúszoboszló & $\begin{array}{l}\text { 'Az egészséges élet csak három szó: } \\
\text { Gyógyvíz, Napfény, Hajdúszoboszló' }\end{array}$ & $\begin{array}{l}\text { 'There are just three things to make you a healthy } \\
\text { fellow: medicinal water, sunshine, and Szoboszlo' }\end{array}$ \\
\hline Nyíregyháza & 'Nyíregyháza többet ad, mint gondolnád' & 'Nyíregyháza gives you more than you would think' \\
\hline Miskolc & $\begin{array}{l}\text { Miskolc, a te helyed } \\
\text { Hello Miskolc } \\
\text { Ez is Miskolc }\end{array}$ & $\begin{array}{l}\text { Miskolc, your place } \\
\text { Hello Miskolc } \\
\text { This is Miskolc, too }\end{array}$ \\
\hline Nagykanizsa & $\begin{array}{l}\text { 'Nagy álmok, nagy lehetőségek, } \\
\text { Nagykanizsa' }\end{array}$ & 'Big dreams, big opportunities, Nagykanizsa' \\
\hline Pápa & 'Egy kicsit mindenki pápai' & 'Everyone's a little bit of Pápa' \\
\hline Sopron & 'Sopronban mindig történik' valami' & 'Something is always happening in Sopron' \\
\hline Szentes & 'Szabadság Szentes Szeretem' & 'Freedom, Szentes, I love it' \\
\hline Telkibánya & $\begin{array}{l}\text { 'Hívja, várja, visszavárja Aranygombos, } \\
\text { Telkibánya' }\end{array}$ & $\begin{array}{l}\text { 'Aranygombos and Telkibánya invites, } \\
\text { welcomes and awaits you again' }\end{array}$ \\
\hline Zalaegerszeg & 'Zalaegerszeg, a Göcsej kapuja' & 'Zalaegerszeg, the gate of Göcsej' \\
\hline
\end{tabular}

Source: Collection of the authors for a tourism project in 2017 
nicated by Debrecen, which also fail to meet the requirements of a good slogan. One of Sopron's slogans, 'Something is always happening in Sopron' also fails to say much about the city, and it could also be argued that so many things actually happen in the city.

Hajdúszoboszló's slogan 'There are just three things to make you a healthy fellow: medicinal water, sunshine, and Szoboszló' combines three promises by the city (health, medicinal water, sunshine) in a single complex sentence, and the Hungarian version of the slogan even rhymes. The 'Everyone's a little bit of Pápa' slogan is an exception in the sense that it does not include any specific promise, and makes you wonder what the city of Pápa may share with everyone.

\section{Category 3: Slogans related to the name of a greater geographic unit}

Another common practice besides including the word 'city' in the slogan is to associate the city with a greater geographical unit, county, region, river, lake, etc. This kind of slogan is based on the notion that the city is less known than the geographical unit it is associated with.

In addition to the "capital" solution discussed above, four cities also use the term "heart" to demonstrate the central role played by the city in the specific region. Mezőkövesd is the 'Heart of Matyó land' in a cultural sense, as no geographical unit has been named after the ethnic group living in the region; however, many people know that the folk tradition of the Matyós is still fostered here.

Table 3. Slogans related to the name of a greater geographic unit

\begin{tabular}{lll}
\hline \multicolumn{1}{c}{ City } & \multicolumn{1}{c}{ Slogan (HUN) } & \multicolumn{1}{c}{ Translation (ENG) } \\
\hline Balf & 'Egészség a Nyugat kapujában' & 'Health in the gate of the West' \\
Felsötárkány & 'A Bükk nyugati kapuja' & 'The Western gate of Bükk' \\
Gyöngyös & 'A Mátra kapuja' & 'The gate of Mátra' \\
Kaposvár és Zselic & 'Kultúra a Zselic ölelésében... & 'Culture embraced by Zselic... where \\
Kahol az élmény szembe jön!' & experiences come in your way' \\
Karcag & 'A Nagykunság fövárosa' & 'The capital of Nagykunság' \\
Kiskörös & 'Élmény a Kunság szívében' & 'Experiences in the heart of Kunság' \\
Komlóska & 'A Zemplén gyöngyszeme' & 'Pearl of Zemplén' \\
Mátrafüred & 'A Mátra nálunk kezdödik' & 'The Mátra starts at us' \\
Mezökövesd & 'Matyóföld szíve' & 'Heart of Matyó land' \\
Parád & 'Palócok központja', & 'The center of Palócland', \\
Sátoraljaújhely & 'Palócok földjén' & 'The land of Palóc people' \\
Sümeg & Zemplén fövárosa & The capital of Zemplén \\
Szigetvár & 'A Pannon táj szíve' & 'The heart of the Pannon landscape' \\
Vásárosnamény & 'Az ország déli kapuja' & 'The Southern gate of the country' \\
Zalaegerszeg & 'A Bereg szíve' & 'The heart of Bereg' \\
\hline
\end{tabular}

Source: Collection of the authors for a tourism project in 2017 
In the case of Parád, a similar idea may have resulted in the slogans 'The center of Palócland' and 'The land of Palóc people'.

Municipalities located on the border of various areas also tend to use the word "gate" in their positioning. Felsőtárkány is 'The Western gate of Bükk', and serves as a kind of starting point for hikers, but Gyöngyös ('The gate of Mátra'), and Zalaegerszeg ('Zalaegerszeg, the gate of Göcsej') also provide very similar promises.

Szigetvár's slogan ('The Southern gate of the country') is based on the historical significance of the city: during the medieval wars of Hungary against the Turks, they were outnumbered by their opponents, but heroically stopped the opposition advancing towards the north several times. The brand of the city based on this heroic act.

\section{Category 4: Slogans related to the name of a greater hydrographic unit}

Slogans based on water form a separate group among slogans related to geographical units, and cities associated with Lake Balaton dominate this group. Besides Hungary's biggest still water, Danube would also be suitable for branding purposes, but it seems that municipalities around Balaton are most active in utilizing their geographical location as a result of their race for tourists. For example, Keszthely and Siófok both position themselves as the capital of Balaton; moreover, Siófok - slightly undervaluing the neighboring municipalities - claims that Lake Balaton actually starts there.

Instead of bathing and water adventures, Balatonberény puts the emphasis on the word "green", using the message 'The green corner of Lake Balaton' thus attempting to break in the niche market of hikers in the region, cyclists, or people who like fresh air.

In addition to Balaton, this category includes city slogans that emphasize the central role of the place. Gárdony is also strengthening its position among neighboring municipalities as the capital of the Velencei Lake.

Table 4. Slogans related to the name of a greater hydrographic unit

\begin{tabular}{lll}
\hline \multicolumn{1}{c}{ City } & \multicolumn{1}{c}{ Slogan (HUN) } & \multicolumn{1}{c}{ Translation (ENG) } \\
\hline Balatonberény & 'A Balaton zöld sarka' & 'The green corner of Lake Balaton' \\
Csorna & 'A Rábaköz szíve', & 'The heart of Rábaköz', \\
Gárdony & 'A Rábaköz fövárosa' & 'The capital of Rábaköz' \\
Keszthely & 'A Velencei-tó fövárosa' & 'The capital of the Velence Lake' \\
Siófok & 'A Balaton fövárosa' & 'The capital of Balaton' \\
Szarvas & 'A Balaton fövárosa', & 'The capital of Lake Balaton', \\
Szolnok & 'Itt kezdödik a Bäläöök szívében, legendák földjén' & 'Lake Balaton starts here' \\
\hline
\end{tabular}

Source: Collection of the authors for a tourism project in 2017 
The city of Szarvas refers to its historical roots and geographical attributes with its complex slogan 'In the heart of the Körös Rivers, in the land of legends', while Szolnok would like to remain known in the public as the 'Capital of the Tisza'.

Another common solution is to create a slogan presenting the city as the 'heart' or the 'capital' of a greater, more known geographical unit (Illustration 3): Kiskőrös: 'Experiences in the heart of Kunság' ('Élmény a Kunság szívében'), Mezőkövesd: 'Heart of Matyó Land' ('Matyóföld szíve'), Siófok: 'Lake Balaton starts here' ('Itt kezdődik a Balaton'), Balatonberény: 'The green corner of Lake Balaton' ('A Balaton zöld sarka'), Gárdony: 'The capital of the Velence Lake' ('A Velencei-tó fővárosa')
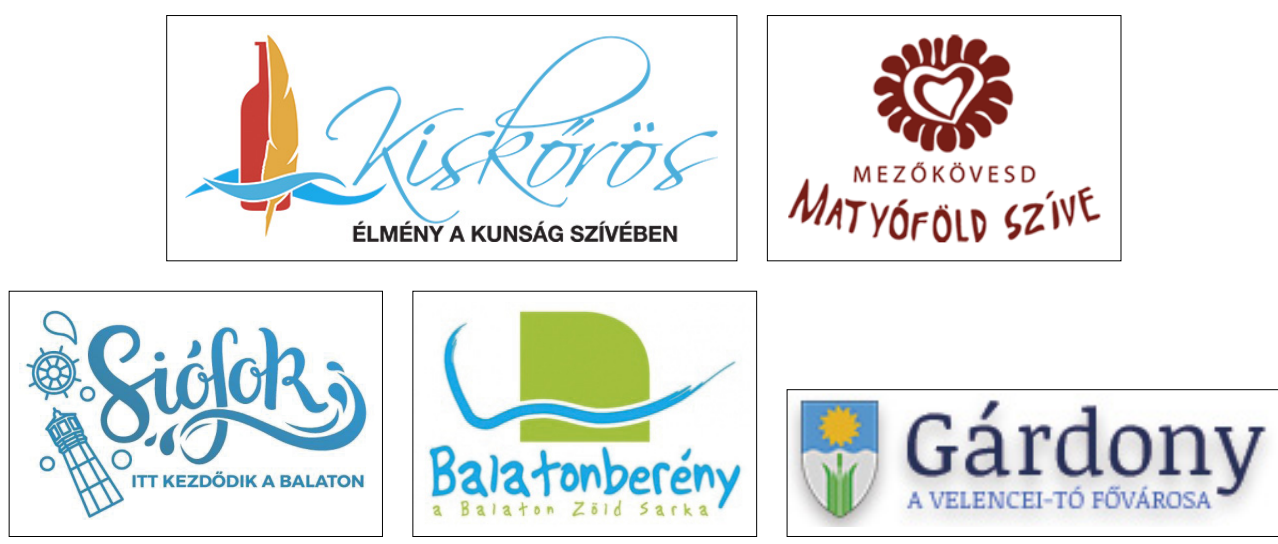

Illustration 3

\section{Category 5: Slogans that emphasize water as an experience}

Slogans carrying the promise of "water experiences" form a separate subgroup - this kind of slogan is applied by nine cities at the moment. As beaches exist in several cities, municipalities also need find the right way to communicate other promises of experiences related to the city. As we have mentioned, Gyula would attract tourists with its historical sites in addition to water ('The historic spa town'). Balatonalmádi ('The friendly spa') would simply use a slogan suggesting its friendliness to stand out from its region, which is rather noisy in a communications sense. Balatonfüzfö used a more creative approach: it has reconsidered its traditional communication with its slogan 'Sea of opportunities', emphasizing the versatility of the city. Bogács would add the less creative "not only" expression to its slogan ('Where bathing is not the only experience'), but it is a fact that the city shows more of itself this way. 
Table 5. Slogans that emphasize water as an experience

\begin{tabular}{lll}
\hline \multicolumn{1}{c}{ City } & \multicolumn{1}{c}{ Slogan (HUN) } & \multicolumn{1}{c}{ Translation (ENG) } \\
\hline Balatonalmádi & 'A barátságos fürdőváros' & 'The friendly spa' \\
Balatonfüzfö & 'Tengernyi lehetöség' & 'Sea of opportunities' \\
Bogács & 'Ahol nem csak a fürdözés élmény' & 'Where bathing is not the only experience' \\
Gyula & 'A történelmi fürdőváros' & 'A historic spa town' \\
Hajdúszoboszló & 'Az egészséges élet csak három szó: & 'There are just three things to make you a healthy \\
Tapolca & Gyógyvíz, Napfény, Hajdúszoboszló' & fellow: medicinal water, sunshine, and Szoboszló' \\
Tata & 'A barlangok és vizek városa' & 'The city of caves and waters' \\
\hline Tiszakécske & 'A vizek városa' & 'The city of gardens and waters' \\
Zalakaros & 'A napfény és a vizek városa' & 'The city of sunshine and waters' \\
\hline
\end{tabular}

Source: Collection of the authors for a tourism project in 2017

\section{Category 6: Wine and gastro slogans}

Currently, Hungary has 22 wine regions. However though, only 7 municipalities base their slogans on this, at least only 7 out of the 91 examined - therefore it is possible that sampling was not perfect, and the analysis of even more slogans should have been performed.

One of the special characteristics of this category is that although the flavour of wines is different in each case, slogans are very similar to each other, and do not facilitate distinction from competitors: the slogans of Villány ('The city of wine'), Gyöngyös ('City of grape and wine'), and Verpelét ('The city of wine and song') differ in only 1-1 word, and do not refer to the differences between the places, and the benefits they provide to visitors.

However, Etyek ('The vineyard of Budapest') is a good example: it refers to its geographical proximity to the capital, and rural lifestyle, relaxation and great wines with the word vineyard. Instead of wine, Sopron chose Blaufränkisch, a famous kind of grape typical of the region, which is a good step even if the slogan 'The city of Blaufränkisch' is not used as a main message.

A subgroup of slogans based on the consumption of wine are gastronomy slogans: it is not surprising that Hungarian country brand communication often based on culinary delights is only accompanied by a few city slogans based on this, for example, those of Békéscsaba: the slogans 'Fence made of sausage', and 'The capital of sausage' both refer to the famous csabai sausage.

Nagykörü highlights cherry ('Cherry garden of Hungary'). Makó, a city originally famous for its quality onions would like to create a promise for its visitors with the slogan 'Not only onions'. 
Table 6. Wine and gastro slogans

\begin{tabular}{lll}
\hline \multicolumn{1}{c}{ Citys } & \multicolumn{1}{c}{ Slogan (HUN) } & \multicolumn{1}{c}{ Translation (ENG) } \\
\hline Békéscsaba & 'Ahol a kerítés is kolbászból van', & 'Fence made of sausage', \\
Etyek & 'A kolbász fővárosa' & 'The capital of sausage' \\
Erdöbénye & 'Budapest szölöskertje' & 'The vineyard of Budapest' \\
Gyöngyös & 'A szölö és a bor városa' & 'A good year in Bénye' \\
Makó & 'Nem csak hagyma' & 'Not only onions' \\
Nagykörü & 'Magyarország cseresznyéskertje' & 'Cherry garden of Hungary' \\
Sopron & 'A Kékfrankos városa' & 'The city of Blaufränkisch' \\
Tokaj & 'Fehér borok, színes kultúra' & 'White wines, colourful culture' \\
Verpelét & 'Bor és a nóta városa' & 'The city of wine and song' \\
Villány & 'A bor városa' & 'The city of wine' \\
\hline
\end{tabular}

Source: Collection of the authors for a tourism project in 2017

\section{Category 7: Family slogans}

Many wellness hotels and destinations in tourism offer "experiences for the whole family", or "family friendly accommodation", so it is somewhat surprising that only three places use the word "family" in their slogans. Sárvár, Igal and Balatonboglár all put family relaxation and vacation in the focus of their communication. This makes Balatonboglár stand out from the competition of municipalities around Lake Balaton, and Igal and Sárvár may offer a way out of gray everyday life with their calm and relaxing atmosphere.

Table 7. Family slogans

\begin{tabular}{lll}
\hline \multicolumn{1}{c}{ City } & \multicolumn{1}{c}{ Slogan (HUN) } & \multicolumn{1}{c}{ Translation (ENG) } \\
\hline Balatonboglár & 'Ahol a család nyaral' & 'Where the family spends the vacation' \\
Sárvár & 'Együtt pihen a család', & 'The family is relaxing together', \\
Igal & 'Condtalan pihenés' & $\begin{array}{l}\text { 'Carefree relaxation' } \\
\text { 'The world is healing with us, the family } \\
\text { is relaxing with us' }\end{array}$ \\
\hline
\end{tabular}

Source: Collection of the authors for a tourism project in 2017

\section{Category 8: Time-based slogans (future and past)}

Cities that focus on future in their messages usually create promises for newly arriving population and investors. From that aspect, Györ uses the term extremely often, as it is one of the favorite in-country migration destination among young people because of employment possibilities offered by the local Audi factory, and the proximity of the Western border. However, one of Szekszárd's messages, 'The city of future' is rather overused. The slogan was actually invoked by a series of economic development measures in 2008, and was used alongside the - not too impressive - slogan 'Livable city'. 
Besides the future, Hungarian places also often use slogans referring to the past as a result of the country's rich historic past. Ópusztaszer is the main monument of Hungarian history. The open air museum and Heritage Park of the municipality justify the 'Enter the past' slogan, which is further emphasized by the 'Historical travel in time' sub-message. Sárvár and Tokaj also focus on the past: although the two municipalities are located far from each other, their common characteristic is that both are cities have a rich cultural heritage as both were founded a long time ago. Hatvan created its slogan combining timelines: 'The heritage of our future' is also a kind of security solution. They do not define the special attributes of the city with this slogan, but it can serve a basis for various messages.

Table 8. Time-based slogans (future and past)

\begin{tabular}{lll}
\hline \multicolumn{1}{c}{ City } & \multicolumn{1}{c}{ Slogan (HUN) } & \multicolumn{1}{c}{ Translation (ENG) } \\
\hline Hatvan & 'Jövönk öröksége' & 'The heritage of our future' \\
Ópusztaszer & 'Lépj be a múltba' & 'Enter the past' \\
Sárvár & 'Évszázadok vonzásában' & 'In the attracion of centuries' \\
Szekszárd & 'Élmény és tradíció' & 'Experience and tradition' \\
Tokaj & 'Ezer éves városa' & 'The city of future' \\
Györ & 'Egészség, Kultúra, Innováció - A jövő Györben épül' & 'Thousand year old history' \\
\hline
\end{tabular}

Source: Collection of the authors for a tourism project in 2017

\section{Category 9: Slogans that emphasize health as a value}

Cities focusing on the serious tradition of thermal spas and health tourism often rely on recovery and health. Currently, 7 cities use this as a main message. This category is dominated by Hajdúszoboszló, which has been using three slogans

Table 9. Slogans that emphasize health as a value

\begin{tabular}{|c|c|c|}
\hline City & Slogan (HUN) & Translation (ENG) \\
\hline Hajdúszoboszló & $\begin{array}{l}\text { 'A reumások Mekkája, a strandolók paradicsoma' } \\
\text { 'Az egészséges élet csak három szó: } \\
\text { Gyógyvíz, Napfény, Hajdúszoboszló' } \\
\text { 'Hajdúszoboszló, a felüdülőhely' }\end{array}$ & $\begin{array}{l}\text { 'Mecca of rheumatism, paradise for bathers' } \\
\text { 'There are just three things to make you a healthy } \\
\text { fellow: medicinal water, sunshine, and Szoboszló' } \\
\text { 'Hajdúszoboszló, the recreation resort' }\end{array}$ \\
\hline Harkány & 'A gyógyító ölelés' & 'The healing embrace' \\
\hline Hévíz & 'Az élet forrása' & 'The source of life' \\
\hline Igal & 'Velünk gyógyul a világ, nálunk pihen a család' & $\begin{array}{l}\text { 'The world is healing with us, } \\
\text { the family is relaxing with us' }\end{array}$ \\
\hline Mórahalom & 'Mártózzon meg az egészségben!' & 'Immerse in health!' \\
\hline Nyírbátor & 'Hit és egészség' & 'Faith and health' \\
\hline Nyíregyháza & 'Hit és egészség' & 'Faith and health' \\
\hline
\end{tabular}

Source: Collection of the authors for a tourism project in 2017 
with this theme. Hévíz and Harkány would target people looking for recovery, Igal counts on families. Nyírbátor and Nyíregyháza also target people practising religion. The municipality of Mórahalom strengthens the more emotional line with its slogan 'Immerse in health!'.

\section{Category 10: Slogans that cannot be classified}

More than $90 \%$ of the Hungarian city slogans that we examined could be classified into the nine groups above, and only 16 examples did not belong to any groups.

Within the category, Szilvásvárad and Villány share a common domain regarding their emphasizing of the proximity of nature. Debrecen and Hortobágy use the term 'Merely wonderful' based on their geographical uniqueness. Tihany emphasizes its peninsular location with its slogan 'The island of experiences'. Szigetvár's Latin text 'Civitas invicta' is the only slogan of our collection originally worded in a foreign language - that is, it is also used in this form in the Hungarian market.

The majority of other slogans in this category (e.g. Eger - 'Your story'; Orfü - 'Recolour your life'; Kisar - 'We treat you'; Nagykanizsa - 'Always one step ahead') unfortunately define messages that are too general. According to aspects explained in the first part of the study, they are not really suitable for positioning or distinction. However, it should once again be noted that if these are accompanied by a strategic marketing communications concept, even a more general slogan can achieve success.

Table 10. Slogans that cannot be classified

\begin{tabular}{|c|c|c|}
\hline City & Slogan (HUN) & Translation (ENG) \\
\hline Debrecen and Hortobágy & 'Pusztán csodálatos' & $\begin{array}{l}\text { 'Merely wonderful' (another possible translation } \\
\text { 'Wonderful in the wilderness') }\end{array}$ \\
\hline Eger & 'A Te történeted' & 'Your story' \\
\hline Hollóháza & 'Hollóháza, ahol alkothatsz!' & 'Hollóháza, where you can create' \\
\hline Kisar & 'Vendégül látjuk' & 'We treat you' \\
\hline Nagykanizsa & 'Mindig egy lépéssel elörébb' & 'Always one step ahead' \\
\hline Nyírbátor & 'A Sárkányok földjén', & 'In the land of dragons' \\
\hline Orfü & 'Színezd újra az életed' & 'Recolour your life' \\
\hline Sátoraljaújhely & 'A megvalósuló álmok otthona' & 'The home of realized dreams' \\
\hline Sárvár & 'Kristálytiszta élmény' & 'Crystal clear experience' \\
\hline Szekszárd & '...ahol feltöltődsz!' & '.. where you recreate' \\
\hline Szigetvár & 'Civitas invicta' & 'Civitas invicta' \\
\hline Szilvásvárad & $\begin{array}{l}\text { 'Otthon a természetben', } \\
\text { 'Ahol a természet átölel' }\end{array}$ & $\begin{array}{l}\text { 'At home in the nature', } \\
\text { 'Where nature embraces you' }\end{array}$ \\
\hline Tihany & 'Az élmények szigete' & 'The island of experiences' \\
\hline Villány & 'Villány, természetesen!' & 'Villány, naturally' \\
\hline Zalaegerszeg & 'Első látásra szeretem' & 'My love at first sight' \\
\hline
\end{tabular}

Source: Collection of the authors for a tourism project in 2017 


\section{Conclusions}

Summarizing the ten categories, most municipalities prefer to use the word 'city' during their branding process: almost $50 \%$ of the slogans examined belong to this group. The names of the cities also appear in every fifth slogan, and positioning as the centre (or, depending on the location, gate) of a greater geographical unit is also a popular solution. Water also has a significant influence on city branding: $17.7 \%$ of Hungarian cities use it in a highlighted position in their communication, $10 \%$ promise experiences with it, and $7.7 \%$ include it to specify a greater unit. Among touristic categories, wine and health had a 7.7\% - 7.7\% "draw", with gastro messages (3.2\%) added to the the former category. Slogans associated with time amount to $6.5 \%$ of the total, and past and future share this in a fifty-fifty ratio.

Table 11. The appearance of typical elements in city slogans

\begin{tabular}{lc}
\hline \multicolumn{1}{c}{ Element in the slogan } & Percentage of cities using it \\
\hline City & $49.4 \%$ \\
Name of the city & $19.6 \%$ \\
\hline Landscape & $16.4 \%$ \\
\hline Capital city & $10.9 \%$ \\
Water - as an experience promise & $10 \%$ \\
Water - as a landscape & $7.7 \%$ \\
Health & $7.7 \%$ \\
Wine & $7.7 \%$ \\
Time (future, past) & $6.5 \%$ \\
Food & $3.2 \%$ \\
\hline
\end{tabular}

At the end of our analysis we must also note that although a slogan is the number one element of the verbal identity of a city, branding a city is not only about the creation of a slogan - it is a much more complex task.

Robert Govers, a prominent expert of the topic, published an article in Place Branding and Public Diplomacy (2013) titled Why place branding is not about logos and slogans. As he explains with great exaggeration, "As places have (more often than not meaningful) names and landmarks, the amount of time and investment generally spent on designing logos and slogans as opposed to actual reputation management for places, seems to be a waste."

Jeremy Hildreth, the other prominent expert of the field uses more gentle words in his article The joys and sorrows of logos and slogans in place branding published in the same journal $(2013$, p. 222.): "In an ideal situation, no more than 10 per cent of a place's identity budget would go toward developing logos and slogans and other signifiers, whereas 90 per cent or more of the budget would be used to find identity-enhancing actions and identity-centric substance, both of which speak louder than words, or logos." 
The opinion of the authors of this study is closer to Hildreth's ideas than Govers' words. Indeed, it is important to emphasize that the significance of slogan (and logos) in city place branding must not be overrated. However, they should not be underrated, either. They may have a serious role in the communication and promotion of the city and the city brand, resulting in a more positive image, more customers of local products and services, and more loyalty to the place.

Therefore, it is very important to consider the aspects presented in the article. When choosing a slogan, we must keep in mind that:

- The original meaning of the word is 'battle cry' - that is, we should choose a slogan that really activates.

- The role of a slogan is to provide clues on what is behind the brand (city), and what its main advantages and values are.

-If a brand name (city name) is part of a slogan, there is greater chance that people remember them - both the slogan and the brand.

- Good slogans are based on facts, or have a musical character - in an ideal case, they carry both characteristics.

Concluding the comprehensive examination of the Hungarian slogans, we can state that the practical advice above could be used in the case of many cities. Although there are good examples (Gyula - 'A historic spa town', Etyek - 'The vineyard of Budapest'), which are primarily based on attractions to distinguish themselves from their competitors, there are still several slogans that are too general, and do not include the values of the specific city (Orfü - 'Recolour your life', Pápa - 'Everyone's a little bit of Pápa'.)

Many Hungarian cities face the challenge that their slogan is not attractive enough for tourists (Paks - 'The city of cooperation'), or it is very similar to that of a competitor (Villány - 'The city of wine', and Gyöngyös - 'City of grape and wine'). The biggest cities such as Győr, Pécs, Debrecen or Miskolc tend to fall in the trap of over-diversification: as a result of their rich offer of attractions, they replace their slogans too often, or use 3-5 slogans simultaneously. This way they cannot focus on highlighting a single word, and confusion arises in the mind of the consumer.

The best examples are usually messages produced during a creative process, representing the characteristic of the city, for example, Mórahalom, a city famous for its popular bath ('Immerse in health!'), Szigetvár using a slogan based on a heroic act in history ('The most heroic city'), or Balatonberény, targeting a niche market of hikers ('The green corner of Lake Balaton'). Successful positioning was also achieved in Sopron and Kecskemét, with slogans involving titles based on oral tradition: the former is mentioned as "The City of loyalty", while the latter as the "Hírös city", both having been used in the "branding" of the cities for several decades. 
Overall, the use of slogans in Hungarian cities shows a very diverse picture: many of them fulfill the functions of an excellent slogan, but in most cases, a version supporting their identity in a better way could be created.

However, it must also be noted that this analysis has not been written with a critical purpose. Creating a good slogan is one of the most difficult tasks in marketing communications, whether we consider cities or "classical" products. We also must not forget that even a slogan that sounds mediocre at first may be filled with content if it is accompanied by a consistent communications concept. In this regard, cities should be congratulated for entering the path of branding, and choosing a slogan that may make them more attractive to tourists (and in certain cases, investors), also increasing the patriotism of local citizens.

\section{Acknowledgements:}

The publication has been created in the Budapest Metropolitan University subproject "Versenyképesség a köz szolgálatában" ("Competitiveness in public service") in the framework of the project $A$ jó kormányzást megalapozó közszolgálat-fejlesztés (Public Service Development Establishing Good Governance) within the Közigazgatás- és Közszolgáltatás-fejlesztési Operatív Program (Public Administration and Public Services Development Operative Programme), KÖFOP-2.1.2.-VEKOP-15, coordinated by the National University of Public Service.

\section{References}

1. Baker, Bill (2007). Destination Branding for Small Cities - The Essentials for Successful Place Branding. Portland, Oregon: Creative Leap Books.

2. Govers, Robert (2013). Why Place Branding is Not about Logos and Slogans. Place Branding and Public Diplomacy, vol. 9, issue 2: 71-75.

3. Healey, Matthew (2009). Mi az a branding? ("What is branding?"). Budapest: Scolar Kiadó.

4. Hildreth, Jeremy (2013). The Joys and Sorrows of Logos and Slogans in Place Branding. Place Branding and Public Diplomacy, vol. 9, issue 4: 217-222.

5. Kotler, Philip - Keller, Kevin Lane (2006). Marketingmenedzsment ("Marketing management"). Budapest: Akadémiai Kiadó.

6. Ogilvy, David (2001). Ogilvy a reklámról ("Ogilvy on advertising"). Budapest: Park Kiadó.

7. Papp-Váry, Árpád (2011). Hogyan lesz a településéből márka? A városmárkázás alapjai ("How can a city become a brand?") (In: Szónoklatok nagykönyve polgármestereknek, "The book of speeches for mayors" series).

8. Papp-Váry, Árpád (2013). A márkanév ereje - Szempontok a sikeres brandépitéshez ("The power of brand names - the aspects of successful brand building"). Pécs-Budapest: Dialóg-Campus Kiadó. 
9. Piskóti, István (2012). Régió- és településmarketing - Marketingorientált fejlesztés, márkázás ("Regional and city marketing - Marketing-focused development and branding"). Budapest: Akadémiai Kiadó.

10. Pride, Roger (2004). A challenger brand: Wales, golf as it should be. In: Morgan, Nigel - Pritchard, Annette - Pride, Roger (ed.): Destination Branding: Creating the Unique Destination Proposition. Oxford: Elsevier Butterworth-Heinemann Publishing.

11. Ries, Al - Trout, Jack (1997). Pozicionálás - Harc a vevók fejében elfoglalt helyért ("Positioning: The Battle for Your Mind"). Budapest: Bagolyvár Könyvkiadó.

12. Tagline Guru (2011). City Branding Survey [URL: http://www.taglineguru.com/ citymottosmonikers.html, accesed: 23 July 2011].

13. Tagline Guru (2011): Slogan and Jingle Survey [URL: http://www.taglineguru.com/ survey05.html, accessed: 23 July 2011]. 